\title{
The Use of Scaffolding Techniques in Language Learning: Extending the Level of Understanding
}

\author{
Yunus Yildiz ${ }^{1} \&$ Bunyamin Celik ${ }^{2}$ \\ ${ }^{1 \& 2}$ English Language Teaching Department, Faculty of Education, Tishk International University, Erbil, \\ Iraq \\ Correspondence: Yunus Yildiz, Tishk International University, Erbil, Iraq. \\ Email: yunus.yildiz@tiu.edu.iq
}

Doi: $10.23918 /$ ijsses.v7i3p148

\begin{abstract}
Due to its contributing influence on language learning, scaffolding is a significant instructional tool. Scaffolding techniques engage learners in collaborative settings under adult guidance. As learners perform tasks successfully with teacher assistance, they develop new abilities and extend their understanding. Teachers withdraw their support when learners grasp new concepts, solidify their understanding and promote their independence in the learning process. Scaffolding has the potential to increase competence of learners in accomplishing their tasks and enable them to become independent learners. This paper attempts to demonstrate the advantages of using scaffolding techniques in language learning settings.
\end{abstract}

Keywords: Scaffolding, Teacher, Assistance, Tasks, Language Learning

\section{Introduction}

Learning is an interactive process; for that reason, the use of scaffolding in the development of knowledge is crucial. That being the case, teachers very often use helpful hints while teaching as learners tackle challenging materials. The clues and directives provided by the teacher allow learners to gain skills, and learners use what they learn to complete other tasks. This temporary support by the teacher helps learners attain achievement without assistance. Scaffolding is an instructional technique in which "a teacher or adult structures a learning task and uses dialog to provide directives and clues that guide the learner's participation in the learning task" (Celce-Muria , 2001, p.195). Scaffolding techniques allow teachers to clarify the purpose and give instructions. Furthermore, teachers use them to promote cooperative tasks and encourage safe relationships. These techniques help learners extend their level of understanding and complete tasks successfully.

\section{Literature Review}

Scaffolding, first used by Wood, Bruner and Ross (1976), refers to instructional techniques used to extend understanding of learners and promote their independence in the learning process. Bruner (1978) defines scaffolding as "the steps taken to reduce the degrees of freedom taken in carrying out some task so that the child can concentrate on the difficult skill s/he is in the process of acquiring" (p. 19). Teachers provide temporary assistance to learners to develop their understanding to complete tasks. This support is given during the tasks which learners cannot accomplish without teacher involvement. The argument here is that, learners will develop new abilities to accomplish similar tasks on their own. In order to enable learners carry out tasks successfully, it is significant to assist them. As learners grasp new concepts and solidify their understanding, teacher support can be withdrawn. It should be noted that scaffolding is effective when teacher assistance is provided in the time of need. Scaffolding has the potential to increase 
competence of learners in accomplishing their tasks and help them become independent learners. Van Lier (1996) states that "even though it does not show up in lesson plans or syllabi, this local or interactional scaffolding may well be the driving force behind good pedagogy, the hallmark of a good teacher" (p. 199). Scaffolding with a clear focus and compatible with curriculum goals will result in better outcome. Bradley and Bradley (2004) have identified three types of scaffolding as being helpful for second language learners:

a) Simplifying the language: The teacher can simplify the language by shortening selections, speaking in the present tense, and avoiding the use of idioms.

b) Asking for completion, not generation: The teacher can have students choose answers from a list or complete a partially finished outline or paragraph.

c) Using visuals: The teacher can present information and ask for students to respond through the use of graphic organizers, tables, charts, outlines, and graphs (p.1).

Scaffolding is related to the zone of proximal development (ZPD) developed by Vygotsky. Vygotsky (1978) defines ZPD as "the distance between the actual developmental level as determined by independent problem solving and the level of potential problem solving as determined through problem solving under adult guidance or in collaboration with more able peers (p. 86). What children can do without help is referred as 'level of actual development' and what children can do with help is referred as 'level of potential development' by Vygotsky. While the former refers to "functions that have already matured" (Vygotsky, 1978, p. 86); the latter refers to "functions that have not yet matured but are in the process of maturation" (Vygotsky, 1978, p. 86). In order for children to progress further, assistance of a more-skilled person holds a significant place. Raymond (2000) summarizes the notion of Vygotsky as "the zone of proximal development is the distance between what children can do by themselves and the next learning that they can be helped to achieve with competent assistance" (p.176).

Wood, Bruner and Ross (1976, p.98) suggest six features of successful scaffolding:

a) Recruitment; teachers need to enlist interest of learners and enable them to stick to the requirements of tasks,

b) Reduction in degrees of freed; teachers need to simplify the size of the task so that learners can manage it easily,

c) Direction maintenance; teachers need to maintain direction and endeavour to keep learners in the field so that they can accomplish objectives of tasks,

d) Marking critical features; teachers need to lay a stress on some significant features of tasks.

e) Frustration control; teachers need to ensure that problem solving process is less stressful for learners,

f) Demonstration; teachers need to provide modelling solutions to tasks so that learners can imitate them.

Motivation is one of the factors affecting success in foreign language learning (Celik \& Yildiz, 2019). It is true that if learners are engaged in tasks which they are interested in, their motivation is triggered. In addition, tasks learners work on should be simplified to facilitate learning. Teachers also need to ensure 
that they create a less stressful learning environment in which learners can accomplish the tasks without fear and anxiety.

Van Lier (2004) lists the features of scaffolding as:

a) Continuity; teachers use tasks which are repeated, and these tasks are connected to one another,

b) Contextual support; a reliable learning environment in which teacher uses visuals, modelling and graphics,

c) Intersubjectivity; collaboration in the learning process allows learners to teach each other,

d) Contingency; teachers should help learners to take responsibility,

e) Handover/Takeover; learners try to attain achievement without teacher assistance,

f) Flow; communication flows in a natural way.

\section{Scaffolding in Language Learning}

It goes without saying that learners accomplish better in a collaborative setting. Scaffolding is an effective teaching and learning strategy in language learning as it engages learners in collaborative activities. It should be noted that interaction is the primary means by which learning takes place (Walqui, 2006). Learners by means of helping each other on tasks become effective participants and develop their understanding (Salma, 2020). Teachers play a significant role as facilitators while learners interact with each other to accomplish tasks. When learners practice the language in a reliable learning environment with someone knowledgeable, they are at an advantage in acquiring the language. An interactive activity with the assistance of an expert person has influence on learning and development.

Social interaction is the basis of learning (Walqui, 2006). Furthermore, it leads to the development of ability and knowledge. Collaboration allows learners to involve in complex social activities and discover new things. Learners with lower level of understanding stand a better chance of finding opportunities to learn in a learning environment in which they cooperate with their capable peers. Teachers should create interactive activities in the classroom in which learners can practice new concepts they have learnt (Mart, 2012; Mart, 2018a). Gardner (1989) states that "first of all, when you are trying to present new materials, you cannot expect them to be grasped immediately. One must approach the issues in many different ways over a significant period of time if there is to be any hope of assimilation" (pp. 158-159). Without support, learners cannot focus their attention on key concepts; hence, learning cannot be promoted.

Walqui (2006) suggests six different types of scaffolding to use with language learners:

a) Modelling;

Modelling is an effective instructional tool which is used very often by teachers. Teachers need to demonstrate a new concept through using different strategies so that learners can observe and imitate them. Learners need clear examples to accomplish similar tasks and acquire new information and skills. Teachers explicitly show how to perform tasks and encourage learners to complete similar activities confidently. Also, modelling eliminates frustration in the learning environment. Anxiety and confusion are negative factors which impede learning. However, modelling creates enjoyment for learners and stimulate them for better achievement. 


\section{b) Bridging:}

The use of learners' prior knowledge has a facilitating role on learning. When teachers employ prior knowledge of learners to teach new concepts, learner engagement and the development of critical thinking is enhanced. In order for learners to fully grasp what they have learnt, they need to build on what they already know about it. It should be noted that understanding occurs through "the weaving of new information into existing mental structures' (Tharp \& Gallimore, 1988, p. 108). In addition, when their prior knowledge is valued, learners pay more attention.

\section{c) Contextualising}

In addition to everyday language, learners should also be aware of academic language; for that reason, teachers should introduce language in context. When language is put in meaningful context, learners have an opportunity to remember the language. Simply put, language becomes accessible if authentic objects are employed while teaching (Mart, 2017).

\section{d) Schema Building}

Schema building is integrating new information into pre-existing knowledge to help students recognize connections. While performing the activities, learners see these connections and endeavour to apply their prior knowledge to new meaningful contexts. The background knowledge of learners about a topic plays a significant role in understanding of new information.

e) Re-presenting text

Learners sometimes may fail to fully understand a text they have read due to its lexical and grammatical items. However, creating meaningful engagements in the classroom results in powerful learning. It is important to provide a platform for language learners in which they experiment with the language via dialogic exchanges (Mart, 2019a). These communication activities enable learners to seek ways to construct meaning and promote their understanding. Passionate teachers know that it is their role to encourage students for an active learning (Mart, 2013a; 2013b; Yildiz, \& Celik, 2017; Yildiz, 2017; Celik, 2017); therefore, they try to maintain learner motivation by raising questions or asking them to create dialogues. For example, holding classroom discussions of literature in the language classroom is an optimal path for the improvement of communication skills (Mart, 2018b; 2019b). The meaningful engagement of learners with each other leads to the development of communicative competence and acquisition of language (Mart, 2019a).

\section{f) Developing Metacognition}

Metacognition helps learners monitor their current level of understanding and learning process. Flavell (1976) points out that "metacognition refers to one's knowledge concerning one's own cognitive processes and products or anything related to them, e.g., the learning-relevant properties of information or data" ( $p$. 232). Metacognition has the potential to enhance learning as it enables learners to control their thoughts and to adjust their own learning. 


\section{Conclusion}

Scaffolding is a useful strategy to employ in language learning and teaching because of the fact that it highly encourages collaborative activities. Interaction greatly contributes to language learning as it facilitates transmission of information. Interactive activities enable teachers to transfer the knowledge to learners to escalate their level from level of actual development to level of potential development. The directives and clues provided by teachers while learners tackle challenging concepts which are beyond their knowledge base can assist them attain higher levels of achievement. Modelling, employing prior knowledge of learners for the purpose of teaching new concepts, presenting the new information in a meaningful context, allowing learners to conduct activities in which they can recognize the connections and providing opportunities to experiment with the language; in particular, by means of communication activities are significant scaffolding strategies which can be implemented in language teaching. For that reason, scaffolding is essential in language learning and teaching in order to extend the level of understanding.

\section{References}

Bradley, K.S. \& Bradley, J.A. (2004). Scaffolding academic learning for second language learners. The Internet TESl Journal, X(5). Retrieved Nov. 28, 2006, from http://iteslj.org/Articles/BradleyScaffolding.

Bruner, 1 S (1978). The Role of Dialogue in Language Acquisition. In Sinclair, A, larvella, R \& Levelt, W J M(eds), The Child's Conception of Language.

Celce-Murcia, M. (Ed.). (2001). Teaching English as a second or foreign language (3rd ed.) Boston: Thomson Heinle.

Celik, B., \& Y1ldiz, Y. (2019). The role of foreign language culture on teaching the language and learner motivation. International Journal of Social Sciences \& Educational Studies, 5(4), 215-223.

Celik, B. (2017). Teaching profession and passion. International Journal of Social Sciences \& Educational Studies, 4(2), 85-92.

Flavell, J. H. (1976). Metacognitive aspects of problem solving. In L. B. Resnick (Ed.), The nature of intelligence (pp. 231-236). Hillsdale, NJ: Erlbaum.

Gardner, H. (1989). To open minds: Chinese clues to the dilemma of contemporary education. New York: Basic Books.

Mart, Ç.T. (2012). Developing speaking skills through reading. International Journal of English Linguistics, 2 (6), 91-96.

Mart, Ç.T. (2013a). A passionate teacher: Teacher commitment and dedication to student learning. International Journal of Academic Research in Progressive Education and Development, 2(1), 437-442.

Mart, Ç.T. (2013b). Commitment to school and students. International Journal of Academic Research in Business and Social Sciences, 3(1), 336-340.

Mart, Ç.T. (2017). Literary texts: A means to promote language proficiency of upper-intermediate level EFL students. Journal of Education in Black Sea Region, 2 (2), 44-55.

Mart, Ç.T. (2018a). From communicative competence to language development. International Journal of English Linguistics, 8(2), 163-167.

Mart, Ç.T. (2018b). The contentious debate over the language literature division. Journal of Language and Cultural Education, 6 (1), 117-127.

Mart, Ç.T. (2019a). Reflections on discussions of literature: A language learning environment to promote speaking skills. The Journal of Social Sciences Research, 5(4), 846-850. 
Mart, Ç.T. (2019b). Reader-Response theory and literature discussions: A springboard for exploring literary texts. The New Educational Review, 56, 78-87.

Raymond, E. (2000). Cognitive characteristics. Learners with mild disabilities (pp. 169-201). Needham Heights, MA: Allyn \& Bacon, Pearson Education Company.

Salma, N. (2020). Collaborative learning: An effective approach to promote language development. International Journal of Social Sciences \& Educational Studies, 7(2), 57-61.

Tharp, R.G., \& Gallimore, R.G. (1988). Rousing minds to life: Teaching, learning, and schooling in social context. Cambridge: Cambridge University Press.

Van Lier, L (1996). Interaction in the language curriculum: Awareness, autonomy and authenticity. London: Longman.

Van Lier, L. (2004). The ecology and semiotics of language learning. Dordrecht: Kluwer Academic Press. http://dx.doi.org/10.1007/1-4020-7912-5

Vygotsky, L.S. (1978). Mind and society: The development of higher mental processes. Cambridge, MA: Harvard University Press.

Walqui, A. (2006). Scaffolding instruction for English language learners: A conceptual framework. International Journal of Bilingual Education and Bilingualism, 9(2), 159-180.

Wood, J., Bruner J. S. \& Ross, G. (1976). The role of tutoring in problem solving. Journal of Child Psychology and Psychiatry, 17, 89-100.

Yildiz, Y. (2017). Components of commitment to the teaching profession. International Journal of Social Sciences \& Educational Studies, 4(2), 115-122.

Yildiz, Y., \& Celik, B. (2017). Commitment to the teaching profession. International Journal of Social Sciences \& Educational Studies, 4(2), 93-97. 